Conselho Nacional de Saúde, Ministério da Saúde
Convênio 4671/2005- Secretaria de Gestão Estratégica e Participativa/ Ministério da Saúde e Ceap/ FSP-USP.

\section{Agenda política para o fortalecimento e desenvolvimento de sistemas universais de seguridade social}

\section{Political agenda for strengthening and developing universal systems of social security}

A I Conferência Mundial sobre o Desenvolvimento de Sistemas Universais de Seguridade Social realizada em Brasília, no período de 1 a 5 de dezembro de 2010, reuniu 677 delegados, provenientes de 90 países, representando governos, movimentos populares, sociais e sindicais, instituições acadêmicas e agências intergovernamentais.

Os objetivos da Conferência foram: a) reconhecer o direito à seguridade social como um direito humano; b) contribuir para o fortalecimento dos sistemas universais; c) identificar conquistas e desafios comuns; d) estimular países, governos e sociedades a adotarem sistemas universais, integrais e eqüitativos como alternativas válidas, éticas e factíveis, orientados à produção de bens públicos; e) analisar as relações do desenvolvimento econômico com as estratégias adotadas pelos países em direção à erradicação da pobreza e à construção da eqüidade entre classes sociais, gerações, gêneros e etnias; f) abrir canais de comunicação e cooperação entre governos, movimentos e instituições acadêmicas para desenvolver políticas, sistemas, serviços e ações, bem como capacidades tecnológicas e humanas; e g) aportar elementos para a construção de agendas nacionais e uma agenda internacional com a finalidade de viabilizar o desenvolvimento de sistemas universais de Seguridade Social.

Os debates desenvolveram-se por meio de atividades autogestionadas, painéis centrais e sessões temáticas e regionais, que possibilitaram a troca de experiências e contribuições importantes que evidenciaram a complexidade dos desafios para os setores governamentais e não-governamentais na construção e qualificação dos sistemas universais de Seguridade Social.

A Conferência teve como debate essencial o universalismo da Seguridade Social compreendida no campo dos direitos humanos, reafirmando como seus princípios irrevogáveis a universalidade, a eqüidade e a integralidade e opondo-se aos discursos e às práticas de mercantilização das políticas sociais.
Nesse sentido, a Conferência indicou a necessidade de discutir a Seguridade Social no marco de um conceito ampliado que compreenda, não apenas a previdência, mas a assistência social; a saúde; o trabalho, a segurança alimentar, econômica e ambiental; a educação; a habitação; o acesso à justiça, à terra, à água e a outras ações do gênero.

As reflexões apontaram elementos que são atribuição da Seguridade Social, como promover o trabalho decente, conforme a Declaração de Direitos e Princípios Fundamentais no Trabalho - Organização Internacional do Trabalho (OIT)/1998, combater a miséria, contribuir para a superação do preconceito étnico, racial, em relação às pessoas com deficiência e das iniqüidades de gênero, geracional, dentre outros. A ratificação e a implementação do convênio 102, da OIT, foram apontadas como passo importante para a ampliação dos níveis de cobertura da proteção social, contribuindo com a construção de sistemas que efetivamente consolidem o universalismo como premissa da Seguridade Social, juntamente com outras políticas que estendam as proteções sociais para o conjunto da população.

Apontaram-se, ainda, acúmulos no sentido de que a universalização da Seguridade Social implica, acima de tudo, uma decisão política de respeito ao direito de todas e todos e a garantia de esse direito ser dever do Estado.

Essa decisão requer construir as condições para sua viabilização, enfatizando o papel do Estado na construção de novas lógicas de organização institucional e financeira, entendendo-se que o universalismo se opõe à focalização e pressupõe uma relação indissociável entre a esfera econômica e social.

A universalização exige não apenas que todos e todas sejam incluídos, mas também que tenham os mesmos benefícios e proteções segundo as suas necessidades, produzindo, assim, a eqüidade. 
A I Conferência Mundial sobre o Desenvolvimento de Sistemas Universais de Seguridade Social viabilizou um espaço plural de diálogo reflexivo e inaugurou uma nova dinâmica democrática entre os setores governamentais e não governamentais no campo da seguridade social em nível internacional, prospectando a possibilidade de construção e aprimoramento desse sistema. Para isso, esse debate se transformará em agenda política, permanente e prioritária, em âmbito nacional e internacional, numa perspectiva que supera a tendência de fragmentação entre os diferentes segmentos da sociedade e das áreas dos governos.

Os participantes do Congresso manifestaram preocupação diante das restrições impostas pela atual crise econômica e social, e da universalização da seguridade social, considerada por muitos como principal medida de proteção dos povos.

Registrou-se, ainda, a vontade dos participantes de dar continuidade aos debates propostos na Conferência, no âmbito dos países e regiões, mantendo-se uma comunicação efetiva entre os presentes. Também foi recomendada a realização da II Conferência Mundial sobre o Desenvolvimento de Sistemas Universais de Seguridade Social. Os conferencistas reafirmaram o disposto no artigo 22, da Declaração Universal dos Direitos Humanos, que consigna a seguridade social como um direito, orientada eticamente pelo princípio da dignidade humana, e que a afiance como componente essencial da construção de sociedades mais justas e igualitárias.

Brasília, 5 de dezembro de 2010. 